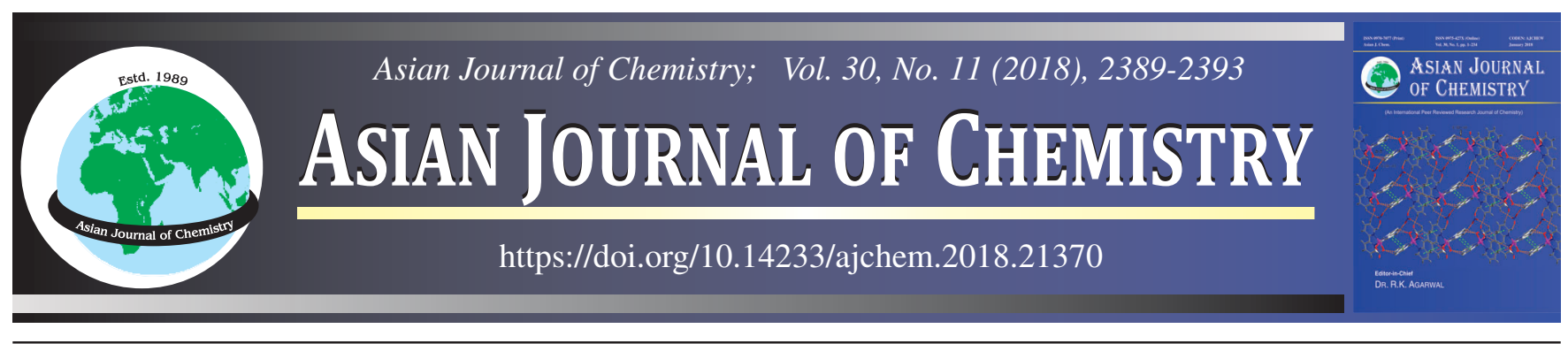

\title{
Simultaneous Quantification of Formoterol Fumarate and Glycopyrrolate Using Reverse Phase High Performance Liquid Chromatography
}

\author{
Anandan Kalaiselvan ${ }^{1,2, *}$, S.R. Xavier Rajarathinam ${ }^{1,2}$ and Saravanan Chandran ${ }^{1,2}$
}

${ }^{1}$ Research and Development Centre, Bharathiar University, Coimbatore-641 046, India

${ }^{2}$ Department of Chemistry, Sacred Heart College (Autonomous), Tirupattur-635 601, India

*Corresponding author: E-mail: adr18phd@gmail.com

Received: 6 April 2018;

Accepted: 14 September 2018;

Published online: 27 September 2018;

AJC-19081

A fully validated and rapid RP-HPLC method suitable for the quantification of formoterol fumarate and glycopyrrolate combination is
reported. Chromatographic separation was achieved on a Sunsil $\mathrm{C} 18$ analytical column $(250 \mathrm{~mm} \times 4.6 \mathrm{~mm}, 5 \mu$ particle size $)$. The analytes
were detected and quantified by photodiode array detector set at $289 \mathrm{~nm}$. Calibration curves were constructed in the range of $4.8-14.4 \mu \mathrm{g} /$
$\mathrm{mL}\left(\mathrm{R}^{2}=0.9997\right)$ with a limit of quantification of $0.279 \mu \mathrm{g} / \mathrm{mL}$ for formoterol fumarate and $9-27 \mu \mathrm{g} / \mathrm{mL}\left(\mathrm{R}^{2}=0.9998\right) \mathrm{with}$ a limit of
quantification $0.239 \mu \mathrm{g} / \mathrm{mL}$ for glycopyrrolate. The method was validated aaccording to $\mathrm{ICH}$ guidelines. The developed and validated $\mathrm{RP}-$
HPLC method was sensitive, selective, robust, accurate and precise for the simultaneous estimation of formoterol fumarate and glycopyrrolate
in quality control laboratories.

Keywords: Formoterol fumarate, Glycopyrrolate, RP-HPLC.

ᄂ - - - - - - - - - - - - - - - - - - - - - - - - - - - - - -

\section{INTRODUCTION}

Formoterol fumarate is a $\beta 2$ selective adrenoceptor agonist and produces bronchodilation in patients with obstructive airways disease [1,2]. Formoterol is principally used in the management of bronchial asthma and other types of allergic airway diseases. Chemically, it is known as (E)-but-2-enedioic acid; N-[2-hydroxy5-[(1S)-1-hydroxy-2-[[(2S)-1-(4-methoxyphenyl) propan-2yl]amino]ethyl]phenyl] formamide (Fig. 1).<smiles>COc1ccc(C[C@@H](C)NC[C@H](O)c2ccc(O)c(NC=O)c2)cc1</smiles>

Fig. 1. Chemical structure of formoterol fumarate
Formoterol fumarate is an official drug in Indian Pharmacopoeia [3] and British Pharmacopoeia [4]. Formoterol fumarate was determined in bulk, pharmaceutical dosage forms, human plasma, serum and urine and rat plasma [5-18]. The techniques for the determination of formoterol fumarate include UV spectrophotometry [5], visible spectrophotometry [6,7], HPLC with UV detection [8-10], HPLC with electrochemical detection [11], HPTLC [12], HPLC-MS/MS [13-15], capillary electrophoresis [16,17], differential-pulse [18] and square-wave voltammetry [18].

Glycopyrrolate is a synthetic anticholinergic drug [19,20]. It also acts as an antispasmodic agent. Glycopyrrolate causes relaxation of smooth muscle and put off the occurrence of painful spasms. Glycopyrrolate also inhibits the release of gastric, pharyngeal, tracheal and bronchial secretions. Chemically, it is described as (1,1-dimethylpyrrolidin-1-ium-3-yl) 2-cyclopentyl-2-hydroxy-2-phenylacetate (Fig. 2).

Glycopyrrolate is an official drug in Indian Pharmacopoeia [21] and United States Pharmacopoeia [22]. HPLC with UV detection [23,24], HPTLC with densitometry [25], ESI-LCMS/MS [26], UHPLC-MS/MS [27], UHPLC-HESI-MS-MS

\footnotetext{
This is an open access journal, and articles are distributed under the terms of the Creative Commons Attribution-NonCommercial 4.0 International (CC BY-NC 4.0) License, which allows others to copy and redistribute the material in any medium or format, remix, transform, and build upon the material, as long as appropriate credit is given and the new creations are licensed under the identical terms.
} 


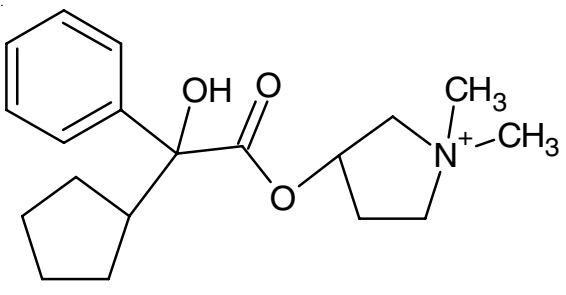

Fig. 2. Chemical structure of glycopyrrolate

[28], GC-MS [29] and capillary electrophoresis [30] techniques are found in the literature for the quantification of glycopyrrolate in bulk, pharmaceutical dosage forms, human plasma, horse urine and plasma and equine urine.

The formoterol fumarate and glycopyrrolate combination is used for the management of airflow obstacle in chronic obstructive pulmonary disease [31,32]. The studied drug combination is not official in any pharmacopeia. Till date, to the best of our literature review, only one RP-HPLC method has been reported for the simultaneous estimation of formoterol fumarate and glycopyrrolate [33]. Herein we report a sensitive and rapid quantification approach of formoterol fumarate and glycopyrrolate by means of RP-HPLC with photodiode array detection. The method was validated following $\mathrm{ICH}$ guidelines [34] and the method had been effectively used in routine analysis of studied drug combination.

The summary of the performance of reported and proposed RP-HPLC methods are shown in Table-1. The developed method has the advantages of sensitive, rapid (less run time), more precise and accurate than the reported method [33]. Furthermore reported method was not fully validated. The volume of sample used for analysis is less in proposed method $(10 \mu \mathrm{L})$.

\section{EXPERIMENTAL}

Reference standard samples of glycopyrrolate and formeterol fumarate was kindly supplied by Lara drugs Pvt Ltd., Hyderabad. Acetonitrile of HPLC grade was obtained from Merck India Ltd., Mumbai. Potassium dihydrogen phosphate of analytical reagent grade was from Sd. Fine Chemicals Ltd., Mumbai. Purified water from a Milli-Q system was used in the analysis.

HPLC instrumentation and conditions: All analyses were done on a Waters HPLC system with a binary HPLC pumps model 2695, photodiode-array (PDA) detector model 2998 and a vacuum degasser. The HPLC system was controlled by Waters Empower2 software. The LC system was equipped with a Sunsil C18 column ( $250 \mathrm{~mm}, 4.6 \mathrm{~mm}, 5 \mu$ particle size) and the separation and analysis were carried out at $25^{\circ} \mathrm{C}$. The mobile phase was $0.1 \mathrm{M}$ dipotassium hydrogen phosphate and acetonitrile $(60: 40 \mathrm{v} / \mathrm{v})$. A constant flow rate of $1 \mathrm{~mL} / \mathrm{min}$ and injection volume of $10 \mu \mathrm{L}$ was employed throughout the analyses. The photodiode array detector was set to $289 \mathrm{~nm}$ to detect and analyze the studied analytes.

Preparation of standard solutions: Mixed stock solutions of glycopyrrolate and formeterol fumarate was prepared by dissolving $9 \mathrm{mg}$ (glycopyrrolate) and $4.8 \mathrm{mg}$ (formeterol fumarate) in $100 \mathrm{~mL}$ of mobile phase in a $100 \mathrm{~mL}$ volumetric flask. Working standard solutions containing 9.0, 13.5, 18.0, 22.5 and $27.0 \mu \mathrm{g} / \mathrm{mL}$ glycopyrrolate and 4.8, 7.2, 9.6, 12.0 and $14.4 \mu \mathrm{g} / \mathrm{mL}$ formoterol fumarate were prepared by aptly diluting the stock solution with mobile phase. The glycopyrrolate and formoterol fumarate working standard solution with concentration 18.0 and $9.6 \mu \mathrm{g} / \mathrm{mL}$, respectively was used for the study of validation parameters.

Preparation of placebo blank solution: $40 \mathrm{mg}$ starch, $35 \mathrm{mg}$ hydroxyl cellulose, $35 \mathrm{mg}$ gum acacia, $20 \mathrm{mg}$ lactose, $35 \mathrm{mg}$ sodium citrate, $40 \mathrm{mg}$ talc, $35 \mathrm{mg}$ sodium alginate and $35 \mathrm{mg}$ magnesium stearate were accurately weighed. All the common excipients were mixed into a homogeneous mixture. A $100 \mathrm{mg}$ of the homogeneous mixture was accurately weighed and transferred to a $100 \mathrm{~mL}$ volumetric flask containing 30 $\mathrm{mL}$ of mobile phase. The contents of the flask were sonicated for $20 \mathrm{~min}$ and filtered using $0.45 \mu \mathrm{m}$ membrane filter. The filtrate was diluted to $100 \mathrm{~mL}$ with mobile phase.

General assay procedure: $10 \mu \mathrm{L}$ of working standard solutions in the concentration range 9-27 $\mu \mathrm{g} / \mathrm{mL}$ (glycopyrrolate) and 4.8-14.4 $\mu \mathrm{g} / \mathrm{mL}$ (formoterol fumarate) was injected into the HPLC system thrice. Using the described chromatographic conditions, the chromatograms and peak area response at each concentration were determined. A calibration curve was drawn with peak area response vs. drug concentration. The regression equation was derived using the obtained data. The concentration of unknown was determined either using the corresponding calibration curve or corresponding regression equation.

\section{RESULTS AND DISCUSSION}

Optimization of chromatographic conditions: Two columns [YMC Pack pro C18 $(250 \times 4.6 \mathrm{~mm} ; 5 \mu \mathrm{m}$ particle size $)$ column and Sunsil C18 $(250 \times 4.6 \mathrm{~mm} ; 5 \mu \mathrm{m}$ particle size) column] with different temperatures were compared by observing the resolution, tailing factor and plate count. Sunsil $\mathrm{C} 18(250 \times 4.6 \mathrm{~mm} ; 5 \mu \mathrm{m}$ particle size $)$ column with $25^{\circ} \mathrm{C}$ yielded the best results. Hence the same column was selected. For mobile phase, $0.1 \mathrm{M}$ potassium dihydrogen orthophosphate and acetonitrile were examined using diverse proportions, $\mathrm{pH}$ and flow rates. Good resolution between glycopyrrolate and formoterol fumarate drugs within short runtime was obtained by an isocratic elution using a mobile phase consisting of 0.1 $\mathrm{M}$ potassium dihydrogen orthophosphate and acetonitrile in the ratio $60: 40(\mathrm{v} / \mathrm{v})$ at a flow rate of $1.0 \mathrm{~mL} / \mathrm{min}$ with $\mathrm{pH} 4.5$.

TABLE-1

PERFORMANCE OF REPORTED AND PROPOSED RP-HPLC METHODS

\begin{tabular}{|c|c|c|c|c|c|c|c|}
\hline Drug & $\begin{array}{l}\text { Run time } \\
\text { (min) }\end{array}$ & $\begin{array}{l}\text { Linearity } \\
(\mu \mathrm{g} / \mathrm{mL})\end{array}$ & LOD $(\mu \mathrm{g} / \mathrm{mL})$ & $\mathrm{LOQ}(\mu \mathrm{g} / \mathrm{mL})$ & $\operatorname{RSD}(\%)$ & Recovery (\%) & Ref. \\
\hline $\begin{array}{l}\text { Formeterol fumarate } \\
\text { Glycopyrrolate }\end{array}$ & 10 & $\begin{array}{c}9-45 \\
4.8-24 \\
\end{array}$ & $\begin{array}{l}\text { Not reported } \\
\text { Not reported }\end{array}$ & $\begin{array}{l}\text { Not reported } \\
\text { Not reported }\end{array}$ & $\begin{array}{c}0.3-0.6 \\
0.3 \\
\end{array}$ & $\begin{array}{l}99.38-100.88 \\
99.85-100.95 \\
\end{array}$ & [33] \\
\hline $\begin{array}{l}\text { Formeterol fumarate } \\
\text { Glycopyrrolate }\end{array}$ & 6 & $\begin{array}{c}4.8-14.4 \\
9-27\end{array}$ & $\begin{array}{l}0.084 \\
0.072 \\
\end{array}$ & $\begin{array}{l}0.279 \\
0.239 \\
\end{array}$ & $\begin{array}{l}0.24 \\
0.12 \\
\end{array}$ & $\begin{array}{c}99.62-99.73 \\
99.97-100.22 \\
\end{array}$ & $\begin{array}{c}\text { Proposed } \\
\text { method }\end{array}$ \\
\hline
\end{tabular}


Detection and analysis of glycopyrrolate and formoterol fumarate was performed using photodiode array detector set at $289 \mathrm{~nm}$. The chromatogram of glycopyrrolate and formoterol fumarate with retention times with optimized chromatographic conditions is shown in Fig. 3.

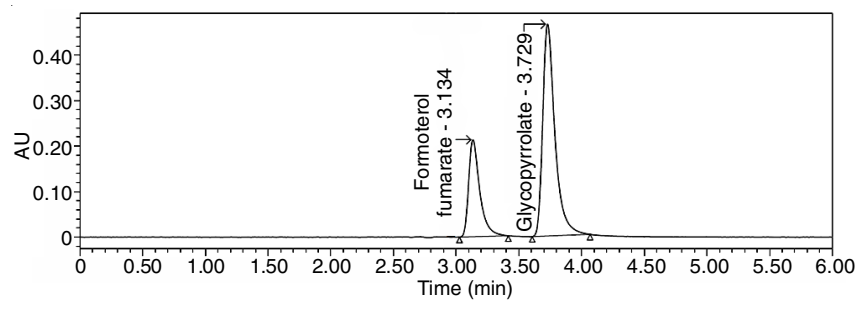

Fig. 3. Chromatogram of glycopyrrolate and formoterol fumarate obtained using optimized chromatographic conditions

Validation of assay method: The method was validated in accordance with the International Conference on Harmonization recommended guidelines [34] for system suitability, linearity, specificity, sensitivity, accuracy, precision and robustness.

System suitability: System suitability study is used to make sure that the reproducibility of the HPLC system is sufficient for the analysis to be done. Parameters including plate count, resolution, tailing factor and relative standard deviation for peak area response and retention time of drugs were calculated using glycopyrrolate and formoterol fumarate standard solution with concentration 18 and $9.6 \mu \mathrm{g} / \mathrm{mL}$, respectively. The parameters required for system suitability test of the method are in acceptable limits as presented in Table-2.

Selectivity: Selectivity of the method was determined by comparing the chromatogram of standard drug (glycopyrrolate
$18 \mu \mathrm{g} / \mathrm{mL}$ and formoterol fumarate $9.6 \mu \mathrm{g} / \mathrm{mL}$ ) with chromatograms of placebo blank and mobile phase blank. The chromatograms of the same are presented (Fig. 4). No peaks were observed in the chromatograms of placebo blank and mobile phase blank. The results indicated that the common excipients and components of the mobile phase did not interfere with the detection and analysis of glycopyrrolate and formoterol fumarate. Hence the method is selective.

Linearity: Linearity was assessed by plotting the peak area response of drug against the concentration of drug using a simple least squares regression. The calibration curves were constructed by plotting the peak area versus the corresponding concentrations of drug in the range of $4.8-14.4 \mu \mathrm{g} / \mathrm{mL}$ for formoterol fumarate and $9-27 \mu \mathrm{g} / \mathrm{mL}$ for glycopyrrolate. The concentration of glycopyrrolate and formoterol fumarate was calculated from the following regression equation:

Formoterol fumarate: $\mathrm{PA}=13499 \mathrm{C}-144.3\left(\mathrm{R}^{2}=0.9997\right)$

Glycopyrrolate: $\mathrm{PA}=17572 \mathrm{C}+2331\left(\mathrm{R}^{2}=0.9998\right)$

where $\mathrm{PA}$ is peak area response, $\mathrm{C}$ is the concentration of drug in $\mu \mathrm{g} / \mathrm{mL}$ and $\mathrm{R}^{2}$ is the regression coefficient.

Sensitivity: Sensitivity of the method is assessed by determining limit of detection (LOD) and limit of quantification (LOQ). The LOD and LOQ of the analytes were calculated using the following equations: $\mathrm{LOD}=3 \mathrm{~s} / \mathrm{m}$ and $\mathrm{LOQ}=10 \mathrm{~s} /$ $\mathrm{m}$. where 's' is the standard deviation of the peak area (five runs) of the standard drug, ' $\mathrm{m}$ ' is the slope of the calibration curve. The calculated LOD was 0.084 and 0.072 and LOQ was 0.279 and 0.239 for formoterol fumarate and glycopyrrolate, respectively. The low values of LOD and LOQ indicated the sufficient sensitivity of the method for the assay of formoterol fumarate and glycopyrrolate.

\begin{tabular}{|c|c|c|c|c|c|c|c|c|c|c|}
\hline \multirow[b]{3}{*}{ Injection No. } & \multicolumn{9}{|c|}{$\begin{array}{l}\text { TABLE-2 } \\
\text { PARAMETERS OF SYSTEM SUITABILITY OF THE DEVELOPED METHOD FOR THE } \\
\text { DETERMINATION OF GLYCOPYRROLATE AND FORMOTEROL FUMARATE }\end{array}$} & \multirow[b]{3}{*}{ Resolution } \\
\hline & \multicolumn{5}{|c|}{ Formoterol fumarate } & \multicolumn{4}{|c|}{ Glycopyrrolate } & \\
\hline & $\begin{array}{c}\text { Retention } \\
\text { time }\end{array}$ & Peak area & $\begin{array}{l}\text { Plate } \\
\text { count }\end{array}$ & $\begin{array}{l}\text { Tailing } \\
\text { factor }\end{array}$ & Resolution & $\begin{array}{c}\text { Retention } \\
\text { time }\end{array}$ & $\begin{array}{c}\text { Peak } \\
\text { area }\end{array}$ & $\begin{array}{l}\text { Plate } \\
\text { count }\end{array}$ & $\begin{array}{l}\text { Tailing } \\
\text { factor }\end{array}$ & \\
\hline 1 & 3.134 & 1297476 & 6547 & 1.57 & - & 3.729 & 3180379 & 7653 & 1.56 & 3.52 \\
\hline 2 & 3.135 & 1291134 & 6604 & 1.54 & - & 3.73 & 3185516 & 7821 & 1.56 & 3.54 \\
\hline 3 & 3.133 & 1286172 & 6598 & 1.55 & - & 3.728 & 3168626 & 7856 & 1.56 & 3.55 \\
\hline 4 & 3.132 & 1324023 & 6512 & 1.59 & - & 3.725 & 3140517 & 7704 & 1.53 & 3.51 \\
\hline 5 & 3.133 & 1290664 & 6633 & 1.52 & - & 3.725 & 3131232 & 7814 & 1.5 & 3.54 \\
\hline Mean & 3.133 & 1297894 & 6579 & 1.554 & - & 3.727 & 3161254 & 7770 & 1.542 & 3.532 \\
\hline $\operatorname{RSD}(\%)$ & 0.036 & 1.167 & 0.737 & 1.739 & - & 0.062 & 0.765 & 1.114 & 1.740 & 0.465 \\
\hline $\begin{array}{l}\text { Recommended } \\
\text { limits }\end{array}$ & $\mathrm{RSD} \leq 2$ & $\mathrm{RSD} \leq 2$ & $>2000$ & $\leq 2$ & - & $\mathrm{RSD} \leq 2$ & $\mathrm{RSD} \leq 2$ & $>2000$ & $\leq 2$ & $>1.5$ \\
\hline
\end{tabular}
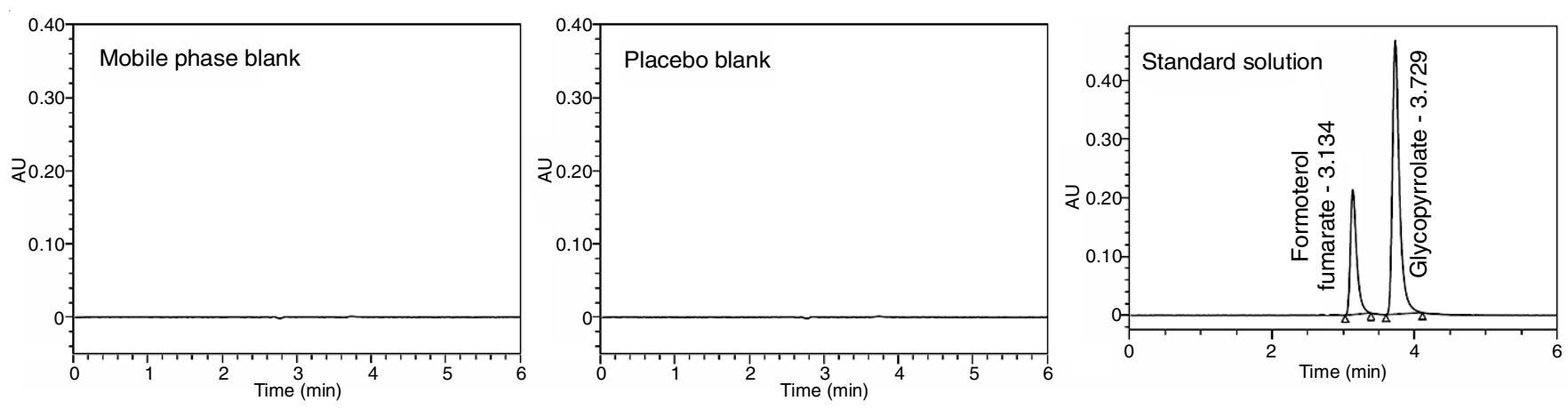

Fig. 4. Chromatograms of selectivity study 
Precision and accuracy: Precision and accuracy were investigated with five replicates of standard drug solution (glycopyrrolate $18 \mu \mathrm{g} / \mathrm{mL}$ and formoterol fumarate $9.6 \mu \mathrm{g} /$ $\mathrm{mL}$ ). Precision was expressed as percentage relative standard deviation (\% RSD) of peak area and accuracy was expressed as a percent of the nominal concentration. The summarized results of precision and accuracy are shown in Table-3. Low $\%$ RSD and good percent assay values proved the precision and accuracy of the method, respectively.

\begin{tabular}{ccc|cc}
\multicolumn{5}{c}{ TABLE-3 } \\
\multicolumn{5}{c}{ PRECISION AND ACCURACY PARAMETERS FOR } \\
\multicolumn{3}{c}{ THE DETERMINATION OF GLYCOPYRROLATE AND } \\
\multicolumn{2}{c}{ FORMOTEROL FUMARATE BY THE PROPOSED METHOD } \\
\hline Injection & \multicolumn{2}{c}{ Formoterol fumarate } & \multicolumn{2}{c}{ Glycopyrrolate } \\
\cline { 2 - 5 } No. & Peak area & Assay $(\%)$ & Peak area & Assay $(\%)$ \\
\hline 1 & 1295903 & 99.65 & 3168753 & 100.14 \\
2 & 1299357 & 99.91 & 3164073 & 99.99 \\
3 & 1292930 & 99.42 & 3167726 & 100.10 \\
4 & 1299680 & 99.94 & 3161951 & 99.92 \\
5 & 1298802 & 99.87 & 3169839 & 100.17 \\
6 & 1293223 & 99.44 & 3160406 & 99.87 \\
Mean & 1296649 & 99.71 & 3165458 & 100.03 \\
RSD $(\%)$ & 0.237 & 0.237 & 0.122 & 0.123 \\
\hline
\end{tabular}

Recovery study: The validity of the proposed method was assessed through recovery study by applying the standard addition technique. For this, standard glycopyrrolate and formoterol fumarate were spiked to placebo at three different concentration levels (50,100 and $150 \%)$. The mean percent recovery of drug at each level was determined. Results given in Table-4 showed that the suggested method is valid and applicable for the analysis of glycopyrrolate and formoterol fumarate with an acceptable percentage recovery. There was no interference from common excipients.
Robustness: Method robustness was investigated to find out whether small variations in chromatographic conditions such flow rate of mobile and column temperature affected system suitability for the analysis of glycopyrrolate and formoterol fumarate. Standard drug solution (glycopyrrolate $18.0 \mu \mathrm{g} / \mathrm{mL}$ and formoterol fumarate $9.6 \mu \mathrm{g} / \mathrm{mL}$ ) was evaluated under test conditions. The system suitability parameters were determined (Table-5). From the results (Table-5), it was observed that small changes in the flow rate of mobile and column temperature had minimal effects on system suitability parameters. Hence the proposed method is robust.

\section{Conclusion}

An analytical method for the simultaneous estimation of glycopyrrolate and formoterol fumarate based on RP-HPLC technique with photodiode array detector was developed. The developed method has done with the necessary validation procedures, following ICH guidelines, for reliable analysis of glycopyrrolate and formoterol fumarate with adequate sensitivity, precision and accuracy for the routine analysis. Also the method proved to have suitable selectivity and robustness for the analysis.

\section{CONFLICT OF INTEREST}

The authors declare that there is no conflict of interests regarding the publication of this article.

\section{REFERENCES}

1. R.A. Bartow and R.N. Brogden, Drugs, 55, 303 (1998); https://doi.org/10.2165/00003495-199855020-00016.

2. W.E. Berger, Ann. Allergy Asthma Immunol., 97, 24 (2006); https://doi.org/10.1016/S1081-1206(10)61365-8.

3. Indian Pharmacopoeia, Ministry of Health and Family Welfare, Government of India, New Delhi, p. 1145 (2007).

4. British pharmacopoeia, Medicines and Health care Products regulatory Agency London, p. 965 (2008).

TABLE-4

DETERMINATION OF GLYCOPYRROLATE AND FORMOTEROL FUMARATE BY THE

PROPOSED METHOD AND APPLICATION OF STANDARD ADDITION TECHNIQUE

\begin{tabular}{|c|c|c|c|c|c|c|c|c|}
\hline \multirow{2}{*}{$\begin{array}{c}\text { Spiked level } \\
(\%)\end{array}$} & \multicolumn{4}{|c|}{ Formoterol fumarate } & \multicolumn{4}{|c|}{ Glycopyrrolate } \\
\hline & $\begin{array}{l}\text { Added } \\
(\mu \mathrm{g} / \mathrm{mL})\end{array}$ & $\begin{array}{l}\text { Found } \\
(\mu \mathrm{g} / \mathrm{mL})\end{array}$ & $\begin{array}{c}\text { Recovery } \\
(\%)\end{array}$ & Mean $(\%)$ & $\begin{array}{c}\text { Added } \\
(\mu \mathrm{g} / \mathrm{mL})\end{array}$ & $\begin{array}{l}\text { Found } \\
(\mu \mathrm{g} / \mathrm{mL})\end{array}$ & $\begin{array}{c}\text { Recovery } \\
(\%)\end{array}$ & Mean $(\%)$ \\
\hline 50 & 4.80 & 4.78 & 99.68 & \multirow{3}{*}{99.73} & 9.00 & 9.00 & 99.99 & \multirow{3}{*}{100.22} \\
\hline 50 & 4.80 & 4.79 & 99.73 & & 9.00 & 9.04 & 100.45 & \\
\hline 50 & 4.80 & 4.79 & 99.79 & & 9.00 & 9.02 & 100.23 & \\
\hline 100 & 9.60 & 9.56 & 99.62 & \multirow{3}{*}{99.68} & 18.00 & 18.03 & 100.14 & \multirow{3}{*}{99.97} \\
\hline 100 & 9.60 & 9.55 & 99.52 & & 18.00 & 17.98 & 99.89 & \\
\hline 100 & 9.60 & 9.59 & 99.89 & & 18.00 & 17.98 & 99.87 & \\
\hline 150 & 14.40 & 14.38 & 99.86 & \multirow{3}{*}{99.62} & 27.00 & 26.98 & 99.91 & \multirow{3}{*}{100.00} \\
\hline 150 & 14.40 & 14.33 & 99.52 & & 27.00 & 27.00 & 100.02 & \\
\hline 150 & 14.40 & 14.32 & 99.48 & & 27.00 & 27.02 & 100.06 & \\
\hline
\end{tabular}

TABLE-5

EFFECT OF VARIABLES ON THE SYSTEM SUITABILITY PARAMETERS OF GLYCOPYRROLATE AND FORMOTEROL FUMARATE

\begin{tabular}{|c|c|c|c|c|c|c|}
\hline \multirow{2}{*}{ Parameter varied } & \multicolumn{3}{|c|}{ Formoterol fumarate } & \multicolumn{3}{|c|}{ Glycopyrrolate } \\
\hline & Plate count & Tailing factor & Resolution & Plate count & Tailing factor & Resolution \\
\hline Flow rate: $0.9 \mathrm{~mL} / \mathrm{min}$ & 6425 & 1.39 & - & 7637 & 1.39 & 3.51 \\
\hline Flow rate: $1.1 \mathrm{~mL} / \mathrm{min}$ & 7625 & 1.57 & - & 8477 & 1.53 & 3.65 \\
\hline Column temperature: $23^{\circ} \mathrm{C}$ & 6117 & 1.54 & - & 7384 & 1.52 & 3.45 \\
\hline Column temperature: $27^{\circ} \mathrm{C}$ & 7416 & 1.58 & - & 8419 & 1.53 & 3.69 \\
\hline
\end{tabular}


5. S.P. Aashish, D.F. Sandip and J.S. Sanjay, Anal. Chem. Indian J., 16, 1 (2016).

6. Md. Gousuddin, S.A. Raju, Md. Sultanuddin and M. Shobha, Int. J. Pharm. Pharm. Sci., 3, 306 (2011).

7. D. Tapkin, G. Erensoy and S. Sungur, Marmara Pharm. J., 20, 275 (2016); https://doi.org/10.12991/mpj.20162030844.

8. S.O. Akapo and M. Asif, J. Pharm. Biomed. Anal., 33, 935 (2003); https://doi.org/10.1016/S0731-7085(03)00425-4.

9. S.A. Raju, Md. Gousuddin, S.A. Raju, Md. Sultanuddin and M. Shobha, Int. J. Biol. Adv. Res., 2, 18 (2011).

10. S. Ahmed, B. Jayakar and M.A. Aleem, Int. J. Pharm. Sci. Res., 2, 319 (2011); https://doi.org/10.13040/IJPSR.0975-8232.2(2).319-24.

11. J. Campestrini, J.B. Lecaillon and J. Godbillon, J. Chromatogr. B. Biomed. Sci. Appl., 704, 221 (1997); https://doi.org/10.1016/S0378-4347(97)00425-8.

12. P. Ashish, Int. J. Adv. Pharma. Anal., 5, 80 (2015).

13. D.G. Mascher, K. Zech, R. Nave, K.M. Kubesch and H.J. Mascher, J. Chromatogr. B. Analyt. Technol. Biomed. Life. Sci., 830, 25 (2006); https://doi.org/10.1016/i.jchromb.2005.10.022.

14. I. Kakubari, H. Dejima, K. Miura, Y. Koga, H. Mizu, T. Takayasu, H. Yamauchi, S. Takayama and K. Takayama, Pharmazie, 62, 94 (2007); https://doi.org/10.1691/ph.2007.2.6134.

15. G. He, J. Lu, X. Wang, Y. Xu, Y. Wu, Y. Dong, L. Shen, Z. He, J. Zhao and H. Yuan, J. Chromatogr. Sci., 52, 848 (2014); https://doi.org/10.1093/chromsci/bmt127.

16. E. Sener, M. Tunçel and H.Y. Aboul-Enein, Arch. Pharm., 336, 226 (2003); https://doi.org/10.1002/ardp.200300733.

17. J.Z., Song, J. Chen, S.J. Tian and Z.P. Sun, J. Pharm. Biomed. Anal., 21, 569 (1999); https://doi.org/10.1016/S0731-7085(99)00158-2.

18. B.T. Demircigil, S.A. Ozkan, O. Coruh and S. Yilmaz, Electroanalysis, 14, 122 (2002); https://doi.org/10.1002/1521-4109(200201)14:2<122::AID-ELAN122 3.0.CO:2-1.

19. J. Howard, J. Wigley, G. Rosen and J. D'mello, J. Clin. Anesth., 36, 51 (2017); https://doi.org/10.1016/j.jclinane.2016.09.013.
20. H.H. Lee, D.W. Kim, D.W. Kim and C. Kim, Korean J. Pain, 25, 28 (2012); https://doi.org/10.3344/kjp.2012.25.1.28.

21. Indian Pharmacopoeia, Government of India. Ministry of Health and Family Welfare New Delhi, vol. II, p. 1278 (2007).

22. United States Pharmacopoeia, Asian Edition, United Pharmacopoeial Convention Inc.: Rockville, USA, p. 2386 (2005).

23. G. Kumaraswamy, P. Parameshwar and A. Ganesh, J. Asian Pharm. Clin. Res., 4, 37 (2011).

24. S. Mishra and V. Arora, Int. J. Pharm. Res. Sch., 5, 101 (2016).

25. S.C. Sohan, S.J. Hitesh, R.C. Sneha and P.G. Sejal, Inventi Impact: Pharm. Anal. Qual. Assur., 171 (2015).

26. M.L. Storme, R.S. t'Kindt, W. Goeteyn, K. Reyntjens and J.F. Van Bocxlaer, J. Chromatogr. B. Analyt. Technol. Biomed. Life. Sci., 876, 24 (2008); https://doi.org/10.1016/j.jchromb.2008.10.013.

27. M.J. Rumpler, R.A. Sams and P. Colahan, J. Chromatogr. B Analyt. Technol. Biomed. Life Sci., 889-890, 130 (2012); https://doi.org/10.1016/j.jchromb.2012.02.008.

28. M.J. Rumpler, R.A. Sams and P. Colahan, J. Anal. Toxicol., 35, 656 (2011); https://doi.org/10.1093/anatox/35.9.656.

29. L.C. Matassa, D. Woodard, R.K. Leavitt, P. Firby and P. Beaumier, $J$. Chromatogr. B Biomed. Sci. Appl., 573, 43 (1992); https://doi.org/10.1016/0378-4347(92)80472-3.

30. L. Zuo, Y. Zhao, F. Ji, M. Zhao, Z. Jiang, T. Sun and X. Guo, Electrophoresis, 35, 3339 (2014); https://doi.org/10.1002/elps.201400170.

31. D. Radovanovic, M. Mantero, G.F.S. Papa, V. Valenti, S. Aliberti, F. Di Marco and P. Santus, Expert. Rev. Respir. Med., 10, 1045 (2016); https://doi.org/10.1080/17476348.2016.1227247.

32. C. Reisner, L.M. Fabbri, E.M. Kerwin, C. Fogarty, S. Spangenthal, K.F. Rabe, G.T. Ferguson, F.J. Martinez, J.F. Donohue, P. Darken, E. St Rose, C. Orevillo, S. Strom, T. Fischer, M. Golden and S. Dwivedi, Respir. Res., 18, 8 (2017); https://doi.org/10.1186/s12931-016-0491-8.

33. N. Md Akram and M. Umamahesh, World J. Pharm. Pharm. Sci., 6, 903 (2017).

34. International Conference on Harmonization, ICH Guidelines, Validation of Analytical Procedures Technical Requirements for Registration of Pharmaceuticals for Human Use: Text and Methodology Q 2 (R1), International Conference on Harmonization, Geneva, Switzerland (2005). 